\title{
Evaluasi Kualitas Dan Kepuasan Pengguna Website Imissu Dengan Penerapan Metode Webqual 4.0
}

\author{
I Ketut Citra Adi Putra ${ }^{1}$, Komang Oka Saputra ${ }^{2}$, Wayan Gede Ariastina ${ }^{3}$ \\ [Submission: 11-04-2019, Accepted: 18-08-2019]
}

\begin{abstract}
Use of Information Technology in academic activities now utilizes integrated information systems. Udayana University has used information technology on academic services into an SSO service (Single Sign On) named IMISSU. But until now, there are still obstacles faced such as the lack of understanding of users in using the IMISSU web and the absence of evaluation of IMISSU's web usage. This study aims to evaluate the quality and satisfaction of IMISSU website users. The research method used a cross sectional design with a kind of descriptive correlative research. The sampling technique used in sampling is a non-probability sampling technique with an accidental sampling approach, the number of respondents used is 121. Data analysis was performed using the Spearman rank test. The results showed a correlation value of 0.855 which means there is a very strong relationship between quality and user satisfaction. Overall the quality variable has a positive influence on user satisfaction, indicated by the results of variable usability quality 0.037 , information quality 0.012 , service quality 0.011 and interface quality 0.001 greater than the probability value of 0.05 .
\end{abstract}

Intisari-Penggunaan Teknologi Informasi dalam kegiatan akademik saat ini telah memanfaatkan sistem informasi terintegrasi. Universitas Udayana telah memakai teknologi informasi pada layanan akademik ke dalam suatu layanan SSO (Single Sign On) yang diberi nama IMISSU. Namun sampai saat ini, masih ada kendala yang dihadapi seperti kurang pahamnya pengguna dalam menggunakan web IMISSU dan belum adanya evaluasi penggunaan web IMISSU. Penelitian ini bertujuan untuk melakukan evaluasi terhadap kualitas dan kepuasan pengguna website IMISSU. Metode penelitian menggunakan desain cross sectional dengan jenis penelitian deskriptif korelatif. Teknik sampling yang digunakan dalam pengambilan sample yakni teknik non-probability sampling dengan pendekatan accidental sampling, jumlah responden yang digunakan adalah 121. Analisis data dilakukan dengan menggunakan uji rank spearman. Hasil penelitian menunjukan nilai korelasi sebesar 0,855 yang berarti ada hubungan yang sangat kuat antara kualitas dengan kepuasan pengguna. Secara keseluruhan variabel kualitas memiliki pengaruh positif terhadap kepuasan pengguna, ditunjukan dari hasil variabel kualitas kegunaan 0,037 , kualitas informasi 0,012 , kualitas layanan 0,011 dan kualitas antarmuka 0,001 lebih besar dari nilai probabilitas 0,05 .

Kata Kunci-Website IMISSU, Kualitas web, kepuasan pengguna.

${ }^{1}$ Mahasiswa, Program Studi Magister Teknik Elektro, Jalan Pulau Singkep GG II No 5, Denpasar Bali, 80222, INDONESIA (62821-44086816; e-mail: citra.adi@gmail.com)

2, 3 Dosen, Program Studi Magister Teknik Elektro, Jalan Panglima Besar Sudirman, Denpasar Bali, INDONESIA (0361239599; fax:0361-239599; e-mail: okasaputra@unud.ac.id, w.ariastina@gmail.com)

I Ketut Citra Adi Putra: Evaluasi Kualitas dan Kepuasan ...

\section{PENDAHULUAN}

Dunia pendidikan saat ini tidak lepas dari pemanfaatan teknologi informasi dalam menyampaikan sebuah informasi. Universitas Udayana merupakan salah satu institusi pendidikan yang telah memanfaatkan teknologi informasi pada layanan akademik dengan menerapkan sistem informasi terintegrasi. Layanan akademik tersebut diberi nama Integrated Management Information System the Strategic of Udayana (IMISSU). Dengan adanya website IMISSU ini diharapkan mampu mengatasi keberagaman data dan dapat mempermudah kegiatan akademik.

Namun, masih banyak masalah yang sering dihadapi dalam penggunaan website kampus, salah satunya adalah kurang pahamnya pengguna dalam menggunakan website sehingga pengguna merasa kurang puas menggunakan layanan tersebut. Dari studi pendahuluan yang dilakukan terhadap mahasiswa yang menggunakan website, didapatkan bahwa sebagian besar mahasiswa mengeluh seringnya terjadi error, adapula mahasiswa yang mengeluhkan tidak tahu cara mengoperasikan website kampus. Hal ini dapat menurunkan kualitas layanan yang ada.

Dalam proses peningkatan layanan diperlukan landasan dalam pengambilan keputusan layanan yang mana yang akan diubah, maka diperlukan bukti nyata tentang evaluasi terhadap kepuasan pengguna. Beberapa penelitian membuktikan bahwa evaluasi layanan website merupakan salah satu cara untuk mengetahui kualitas website.

Evaluasi terhadap kualitas website bisa ditentukan dengan cara melihat bagaimana pengguna merasa puas menggunakan website tersebut. Metode umum yang dapat digunakan dalam menilai kualitas suatu website dilihat dari pengguna akhir adalah metode WebQual. Metode WebQual merupakan metode yang dikembangkan dari metode ServQual, metode yang digunakan dalam mengukur kualitas jasa [1].

Penelitian tentang evaluasi kualitas pada website dengan WebQual 4.0 telah dilakukan sebelumnya. Seperti yang dilakukan [1] melakukan penelitian untuk mengetahui bagaimana tingkat kepuasan pengguna terhadap web berbasis akademik. Metode yang diajukan adalah menggunakan metode WebQual 4.0. Hasil penelitian menunjukkan kualitas dari informasi dan kualitas dari kegunaan tidak mempunyai pengaruh terhadap kepuasan pengguna. Penelitian oleh [2] untuk menguji kualitas website dengan mencari faktor apa yang menjadi pengaruh dalam meningkatkan kualitas website bila dilihat dari sisi kepuasan pengguna. Hasil dari penelitian menunjukan dimensi service interaction paling rendah dari ketiga dimensi WebQual 4.0. Penelitian yang dilakukan oleh [3] berfokus pada usability, information quality, dan service interaction quality berdasarkan voice of customer (persepsi pengguna). Hasil penelitian menyebutkan bahwa semua p-ISSN:1693 - 2951; e-ISSN: 2503-2372 
variabel yang ada termasuk ke dalam kategori dengan tingkat kepuasan yang tinggi. [4] melakukan penelitian untuk menganalisis layanan website e-commerce terhadap kepuasan pengguna dengan metode WebQual 4.0. Hasil penelitian menunjukkan bahwa faktor yang paling penting terhadap kepuasan pelanggan adalah usability. [5] dalam penelitiannya melakukan modifikasi terhadap metode webqual 4.0 dengan cara memasukkan dimensi baru tentang daya Tarik visual ke dalam dimensi webqual. Dimensi tersebut kemudian menjadi dimensi keempat yang berkaitan dengan kualitas antarmuka pengguna. Evaluasi terhadap kualitas layanan website pemerintah daerah dilakukan oleh [6] menggunakan metode WebQual. Hasil penelitian menyebutkan kualitas layanan website baik dengan faktor yang mempengaruhi adalah kualitas informasi, kualitas interaksi layanan dan kualitas desain website.

Berdasarkan uraian diats penelitian ini menggunakan metode webqual kebanyakan digunakan pada website company profile, government, portal berita maka pada penelitian ini mencoba menerapkan metode Webqual dengan penambahan dimensi kualitas antarmuka pada website berbasis system informasi.

Luaran dari penelitian memiliki tujuan untuk melakukan evaluasi tentang pengaruh kualitas website IMISSU terhadap kepuasan pengguna dilihat dari sudut pandang pengguna akhir.

\section{KAJIAN PUSTAKA}

\section{A. Evaluasi}

Evaluasi merupakan kegiatan yang memiliki proses sistematis dalam mengumpulakn dan evaluasi bahan dengan objektif tentang pertanyaan yang berhubungan melalui aksi atau peristiwa, mencocokan pada parameter yang dipilih, serta memberikan hasil dari informasi yang dapat digunakan sebagai contoh pada saat melaksanakan evaluasi dan pengembangan lanjutnan [7].

\section{B. Kualitas}

Kualitas disebutkan sebagai keseluruhan dari fitur serta karakteristik yang terdapat pada produk atau jasa yang mampu memenuhi kebutuhan [8].

\section{Website}

Website dapat diartikan sebagai serangkaian halamanhalaman yang bisa menampilkan informasi berbentuk tulisan, gambar, suara atau gabungan dari semuanya [9] yang memiliki struktur kompleks, yang berisi tag-tag HTML, tautan dan javascript [10]. Interaksi dalam web dibagi menjadi 3 bagian yaitu permintaan, pemrosesan dan jawaban [11].

\section{Kepuasan}

Kepuasan terhadap suatu website adalah sebuah proses dari keperluan dan harapan dari pengguna terhadap website tersebut. Keseluruhan dari tanggapan kepuasan biasanya mengarah ke hal yang positif terhadap website [12]. Kepuasan pengguna sistem informasi merupakan acuan yang dapat digunakan untuk menilai tingkat keberhasilan penggunaan, kepuasan dapat berupa penilaian dari sisi baik atau tidak baik, dan cocok atau tidak cocoknya sistem informasi dengan tujuan penggunanya[13].

\section{Metodologi Penelitian}

\section{A. Kerangka Berpikir}

Kerangka pemikiran yang dikemukan adalah merupakan uraian dari telaah pustaka pada penelitian terdahulu yakni Usability Quality (kualitas kegunaan) dapat diartikan sebagai kualitas yang berhubungan dengan navigasi serta tampilan yang disampaikan ke pengguna. Information Quality (kualitas informasi) tentang isi dari website, ketelitian penyampaian informasi bagi pengguna seperti akurasi, format dan relevansi. Service Interaction Quality (kualitas interaksi layanan) yang dihubungkan dengan riwayat berinteraksi dan pelayanan yang dirasakan oleh pengguna [1][2][3]. User Interface Quality (kualitas antarmuka) sebagai kualitas yang berhubungan dengan daya tarik visual [4][5][6]. User Statisfaction (kepuasan pengguna) merupakan pemikiran/perkiraan dari pengguna perihal kepuasan menurut keseluruhan akan kualitas layanan website yang dirasakan [13] sehingga variabel pada penelitian ini dapat dirumuskan sebagai berikut:

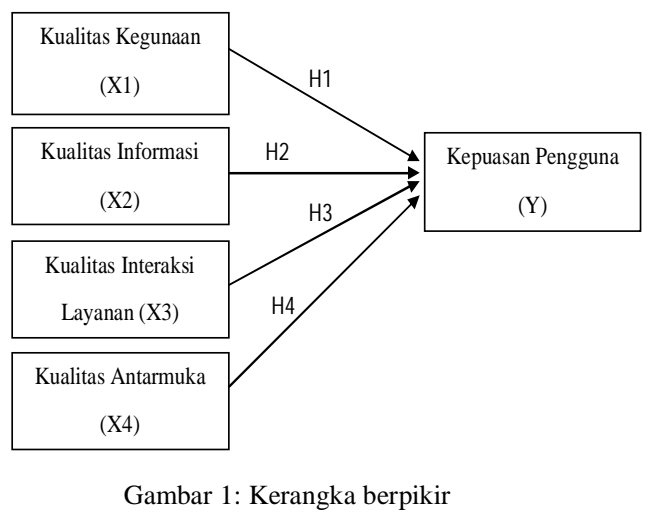

Berdasarkan kerangka berpikir peneliti ingin melihat ini melihat bagaimana hubungan kualitas berpengaruh terhadap kepuasan pengguna.

\section{B. Hipotesis}

Berdasarkan kerangka berpikir maka dirumuskan hipotesis berikut:

H1: Apakah secara positif dan signifikan kualitas kegunaan memiliki hubungan dengan kepuasan pengguna

H2: Apakah secara positif dan signifikan kualitas informasi memiliki hubungan dengan kepuasan pengguna

H3: Apakah secara positif dan signifikan kualitas interaksi layanan memiliki hubungan dengan kepuasan pengguna

H4: Apakah secara positif dan signifikan kualitas antar muka memiliki hubungan dengan kepuasan pengguna

\section{Rancangan Penelitian}

Rancangan penelitian adalah deskriptif cross sectional dengan jenis penelitian deskriptif korelatif. Adapun rancangan alur penelitian pada penelitian ini adalah sebagai berikut. 


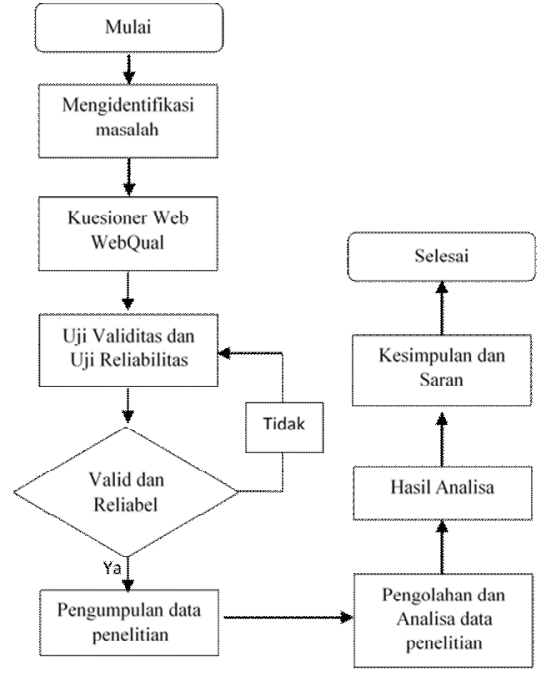

Gambar 2: Alur Penelitian

\section{Lokasi dan Waktu Penelitian}

Lokasi penelitian dilakukan pada Prodi Magister IKM Fakultas Kedokteran Unud. Pengumpulan data akan dilaksanakan dalam jangka waktu 2 bulan.

\section{Sumber Data}

Populasi adalah mahasiswa pada Prodi Magister Ilmu Kesehatan Masyarakat, Fakultas Kedokteran UNUD pada Tahun 2018.

Sampel penelitian berdasarkan populasi yang dipilih dan dapat menggantikan populasi yang ada. Pemilihan teknik sampling menggunakan teknik non probability sampling dengan pendekatan Accidental di mana sampel ditentukan berdasarkan aksesibilitas nyaman dan kedekatan responden kepada peneliti. Sebelum dijadikan sampel terlebih dahulu harus sesuai dengan kriteria yang ditetapkan.

1. Kriteria inklusi adalah:

a) Mahasiswa aktif pada program studi magister Ilmu Kesehatan Masyarakat

b) Mahasiswa yang bersedia berpartisipasi dalam penelitian

2. Kriteria eksklusi adalah:

a) Mahasiswa yang sedang cuti akademik

b) Mahasiswa yang tidak bersedia berpartisipasi dalam penelitian

Total populasi yang digunakan adalah sebanyak 174 orang mahasiswa. Perhitungan besaran sampel mengacu pada metode slovin [14].(1)

$$
n=\frac{N}{1+N(e)^{2}}
$$

dengan:

$\mathrm{n}=$ jumlah sampel

$\mathrm{N}=$ jumlah populasi

$\mathrm{e}=$ batas toleransi kesalahan

Sehingga berdasarkan perhitungan menggunakan metode slovin, sampel pada penelitian ini berjumlah 121 responden.

I Ketut Citra Adi Putra: Evaluasi Kualitas dan Kepuasan ...

\section{Variabel Penelitian}

Variabel pada penelitian ini merupakan variabel dari metode WebQual 4.0 yang telah dimodifikasi[5][6][15]dan digunakan sebagai pengukuran kualitas sebuah website. Selanjutnya variabel penelitian dijabarkan sebagai berikut:

1. Variabel Independen (X) atau variabel bebas. Variabel ini merupakan terjadinya perubahan pada varibel dependen/terikat. Pada penelitian ini menggunakan empat variabel bebas yakni:
a. Kualitas Kegunaan $\left(\mathrm{X}_{1}\right)$
b. Kualitas Informasi $\left(\mathrm{X}_{2}\right)$
c. Kualitas Interaksi Layanan $\left(\mathrm{X}_{3}\right)$
d. Kualitas Antarmuka $\left(\mathrm{X}_{4}\right)$
Kualitas dikategorikan sebagai berikut :
a. Baik jika nilai $X \geqslant$ median
b. Kurang baik jika nilai $X \leqslant$ median

2. Variabel Dependen (Y) atau variabel terikat, merupakan variabel yang menerima pengaruh, karena adanya variabel bebas. Pada penelitian ini variabel terikat adalah Kepuasan Pengguna. Kepuasan Pengguna dikategorikan dengan menggunakan metode cut off point sebagai berikut:
a. Puas jika nilai $X \geqslant$ median
b. Kurang puas jika nilai $X \leqslant$ median

\section{Instrumen Penelitian}

Instrumen penelitian yang digunakan adalah kuesioner. Skala perhitungan menggunakan skala likert dengan empat tingkatan jawaban, yang dapat dilihat pada tabel 1. berikut.

TABEL I

INSTRUMEN SKALA LIKERT

\begin{tabular}{|c|l|c|}
\hline No & \multicolumn{1}{|c|}{ INSTRUMEN SKALA LIKERT } & Skor \\
\hline 1 & Sangat Setuju & 4 \\
\hline 2 & Setuju & 3 \\
\hline 3 & Tidak Setuju & 2 \\
\hline 4 & Sangat Tidak Setuju & 1 \\
\hline
\end{tabular}

\section{Uji Validitas}

Pengujian terhadap instrumen perlu dilakukan untuk menentukan apakah instrumen yang digunakan valid. Pengujian dilakukan berdasarkan tingkat signifikansi 0,05 . Adapun kriteria dalam pengujian menggunakan perbandingan antara $r$ hitung dengan $r$ tabel. Perbandingan tersebut dapat dirumuskan sebagai berikut [16].

- $r$ hitung lebih tinggi atau sama dengan $r$ tabel maka instrumen dapat dikatakan valid.

- $r$ hitung lebih rendah atau sama dengan $r$ tabel maka instrumen dapat dikatakan tidak valid.

\section{Uji Reliabilitas}

Untuk menentukan indikator atau variabel yang digunakan reliabel, dapat dilakukan uji menggunakan metode Alpha (Cronbach's). Kriteria nilai Jika nilai alpha bernilai diatas 0,80 maka nilai reliabel dan konsisten, reliabilitas kuat. Jika nilai alpha kurang dari 0,50 dapat dikatakan nilai reliabilitas rendah. 
Jika nilai alpha pada variabel dinyatakan rendah, ada satu atau beberapa variabel yang digunakan tidak reliabel [16].

\section{Analisis Data}

Analisa data dalam penelitian ini menggunakan analisa data kuantitatif yang meliputi beberapa tahap, yaitu:

a) Editing. Pada tahap ini semua kuisioner yang sudah diisi oleh responden dikumpulkan, diperiksa kelengkapan dan jelas penulisannya.

b) Coding. Pada tahap ini dilakukan pemberian nomer dengan kode tertentu untuk memudahkan memasukan data.

c) Scoring. Pada tahap ini adalah menghitung nilai atau skor pada setiap jawaban yang dpilih oleh responden

d) Data entry. Tahap ini dilakukan dengan memasukan data ke dalam tabel yang sesuai dengan kode yang telah ditetapkan.

e) Analisis deskriptif dilakukan untuk mendeskripsikan distribusi karakteristik responden dan kompetensi sosial. Data yang bersifat kategorik disajikan dengan presentase dan jumlah, sedangkan data yang bersifat numerik disajikan dengan mean dan standar deviasi.

f) Uji normalitas data dilakukan sebagai uji dalam menentukan apakah variabel yang digunakan berdistribusi normal atau tidak.

g) Analisis Regresi adalah analisis tentang ketergantungan variabel dengan satu atau lebih variabel.

Uji Hipotesis. Uji yang dilakukan dengan cara menganalisis data melalui uji regresi berganda[17]. Penggunaan analisis ini karena pada penelitian terdapat variabel independen lebih dari satu.

\section{IV.HASIL DAN PEMBAHASAN}

\section{A. Analisis Deskriptif}

Gambaran dari karakteristik responden dalam penelitian ini dijabarkan berdasarkan dari jenis kelamin dan umur.

TABEL II.

DISTRIBUSI KARAKTERISTIK RESPONDEN

\begin{tabular}{ccc}
\hline $\begin{array}{c}\text { Karakteristik } \\
\text { Responden }\end{array}$ & $\begin{array}{c}\text { Frekuensi } \\
\text { (orang) }\end{array}$ & $\begin{array}{c}\text { Proporsi } \\
(\boldsymbol{\%})\end{array}$ \\
\hline $\begin{array}{c}\text { Jenis Kelamin } \\
\text { Laki-Laki }\end{array}$ & 27 & 22.3 \\
Perempuan & 94 & 77.7 \\
Umur & 12 & \\
$<$ 25 tahun & 45 & 9.9 \\
26-29 tahun & 44 & 37.2 \\
30-39 tahun & 18 & 36.4 \\
40-49 tahun & 2 & 14.9 \\
$>$ 50 tahun & & 1.7 \\
\hline
\end{tabular}

Jumlah responden laki-laki sebanyak $22.3 \%$ dan $77,7 \%$ responden adalah perempuan. Sedangkan dari kelompok umur, sebanyak $9.9 \%$ berumur kurang dari 25 tahun, $37.2 \%$ berumur 26-29 tahun, 36, berumur 30-39 tahun, $14.9 \%$ berumur $40-49$ tahun dan $1.7 \%$ berumur lebih dari 50 tahun.
TABEL III.

DISTRIBUSI JAWABAN KUALITAS KEGUNAAN

\begin{tabular}{|c|c|c|c|c|}
\hline \multirow[t]{2}{*}{ No } & \multirow[t]{2}{*}{ Dimensi Kualitas } & \multicolumn{3}{|c|}{ Jumlah Jawaban dan Persentase } \\
\hline & & $\begin{array}{c}\text { Tidak } \\
\text { Setuju } \\
\text { n (\%) }\end{array}$ & $\begin{array}{l}\text { Setuju } \\
\text { n (\%) }\end{array}$ & $\begin{array}{c}\text { Sangat } \\
\text { Setuju } \\
(\%)\end{array}$ \\
\hline \multicolumn{5}{|c|}{ Usability Quality } \\
\hline 1 & Mudah dioperasikan & $2(1,7)$ & $77(63,6)$ & $42(34,7)$ \\
\hline 2 & $\begin{array}{l}\text { Interaksi jelas dan } \\
\text { mudah dipahami }\end{array}$ & $4(3,3)$ & $81(66,9)$ & $36(29,8)$ \\
\hline 3 & $\begin{array}{l}\text { Mudah } \\
\text { dinavigasikan }\end{array}$ & $8(6,6)$ & $85(70,2)$ & $28(23,1)$ \\
\hline 4 & Mudah digunakan & $4(3,3)$ & $84(69,4)$ & $33(27,3)$ \\
\hline 5 & $\begin{array}{l}\text { Memiliki tampilan } \\
\text { menarik }\end{array}$ & $10(8,3)$ & $85(70,2)$ & $26(21,5)$ \\
\hline 6 & $\begin{array}{l}\text { Mempunyai desain } \\
\text { sesuai tipe }\end{array}$ & & $95(78,5)$ & $26(21,5)$ \\
\hline 7 & $\begin{array}{l}\text { Mengandung nilai } \\
\text { kompetensi }\end{array}$ & $4(3,3)$ & $92(76,0)$ & $25(20,7)$ \\
\hline 8 & $\begin{array}{l}\text { Memberikan kesan } \\
\text { positif }\end{array}$ & $3(2,5)$ & $84(69,4)$ & $34(28,1)$ \\
\hline
\end{tabular}

TABEL IV.

ANALISIS DESKRIFTIF KUALITAS KEGUNAAN

\begin{tabular}{|c|c|c|c|}
\hline Variabel & n (\%) & $\begin{array}{c}\text { Std. } \\
\text { Deviation }\end{array}$ & Median \\
\hline Kualitas Kegunaan & 25,78 & 3,048 & 25,00 \\
\hline Baik & $62(51,20 \%)$ & & \\
\hline Kurang Baik & $59(48,80 \%)$ & & \\
\hline
\end{tabular}

Pada tabel 4 menunjukan nilai rata-rata 25,78, standar deviasi 3,048 dan nilai tengah 25,00. Proporsi responden terhadap nilai kualitas kegunaan $51,20 \%$ responden menyatakan kualitas kegunaan baik dan 48,80\% kurang baik.

TABEL V.

DISTRIBUSI JAWABAN KUALITAS INFORMASI

\begin{tabular}{|c|c|c|c|c|}
\hline \multirow[t]{2}{*}{ No } & \multirow[t]{2}{*}{ Dimensi Kualitas } & \multicolumn{3}{|c|}{ Jumlah Jawaban dan Persentase } \\
\hline & & $\begin{array}{c}\text { Tidak } \\
\text { Setuju } \\
\text { n (\%) }\end{array}$ & $\begin{array}{l}\text { Setuju } \\
\text { n (\%) }\end{array}$ & $\begin{array}{c}\text { Sangat } \\
\text { Setuju } \\
(\%)\end{array}$ \\
\hline \multicolumn{5}{|c|}{ Information Quality } \\
\hline 1 & Informasi akurat & $4(3,3)$ & $86(71,1)$ & $31(25,6)$ \\
\hline 2 & $\begin{array}{l}\text { Informasi dapat } \\
\text { dipercaya }\end{array}$ & & $87(71,9)$ & $34(28,1)$ \\
\hline 3 & $\begin{array}{l}\text { Informasi tepat } \\
\text { waktu }\end{array}$ & $14(11,6)$ & $82(67,8)$ & $25(20,7)$ \\
\hline 4 & Informasi relevan & $2(1,7)$ & $87(71,9)$ & $32(26,4)$ \\
\hline 5 & $\begin{array}{l}\text { Informasi mudah } \\
\text { dipahami }\end{array}$ & $1(0,8)$ & $90(74,4)$ & $30(24,8)$ \\
\hline 6 & Informasi detail & $7(5,8)$ & $87(71,9)$ & $26(21,5)$ \\
\hline 7 & $\begin{array}{l}\text { Informasi sesuai } \\
\text { format }\end{array}$ & $1(0,8)$ & $89(73,6)$ & $31(25,6)$ \\
\hline
\end{tabular}

TABEL VI.

ANALISIS DESKRIFTIF KUALITAS INFORMASI

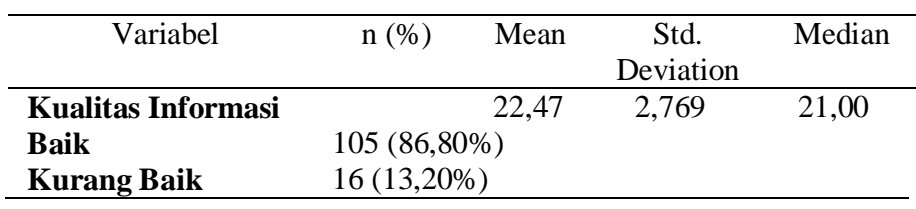


ANALISI DESKRIFTIF KUALITAS ANTARMUKA

Pada tabel 6 menunjukan nilai rata-rata 22,47, standar deviasi 2,769 dan nilai tengah 21,00. Proporsi responden terhadap nilai kualitas informasi $86,80 \%$ responden menyatakan kualitas informasi baik dan $13,20 \%$ kurang baik.

TABEL VII.

DISTRIBUSI JAWABAN KUALITAS INTERAKSI LAYANAN

\begin{tabular}{|c|c|c|c|c|}
\hline \multirow[t]{2}{*}{ No } & \multirow[t]{2}{*}{ Dimensi Kualitas } & \multicolumn{3}{|c|}{ Jumlah Jawaban dan Persentase } \\
\hline & & $\begin{array}{c}\text { Tidak } \\
\text { Setuju n } \\
(\%)\end{array}$ & $\begin{array}{l}\text { Setuju } \\
\text { n }(\%)\end{array}$ & $\begin{array}{c}\text { Sangat } \\
\text { Setuju } \\
(\%)\end{array}$ \\
\hline \multicolumn{5}{|c|}{ Service Interaction Quality } \\
\hline 1 & $\begin{array}{l}\text { Memiliki reputasi } \\
\text { baik }\end{array}$ & $4(3,3)$ & $84(69,4)$ & $33(27,3)$ \\
\hline 2 & $\begin{array}{l}\text { Memberikan rasa } \\
\text { aman }\end{array}$ & $3(2,5)$ & $86(71,1)$ & $32(26,4)$ \\
\hline 3 & Layanan sesuai janji & $4(3,3)$ & $92(76,0)$ & $25(20,7)$ \\
\hline 4 & Personalisasi & $5(4,1)$ & $93(76,9)$ & $23(19,0)$ \\
\hline 5 & Ruang Komunikasi & $14(11,6)$ & $84(69,4)$ & $23(19,0)$ \\
\hline
\end{tabular}

TABEL VIII.

ANALISIS DESKRIFTIF KUALITAS INTERAKSI LAYANAN

\begin{tabular}{lcccc}
\hline \multicolumn{1}{c}{ Variabel } & $\begin{array}{c}\mathbf{n} \\
(\boldsymbol{\%})\end{array}$ & Mean & $\begin{array}{c}\text { Std. } \\
\text { Deviation }\end{array}$ & Median \\
\hline $\begin{array}{l}\text { Kualitas Layanan } \\
\text { Baik }\end{array}$ & $\begin{array}{c}15,87 \\
\text { Kurang Baik }\end{array}$ & $\begin{array}{l}106 \\
(87,60 \%)\end{array}$ & 15 \\
\hline
\end{tabular}

Pada variabel kualitas interaksi layanan nilai rata-rata 15,47 , standar deviasi 2,035 dan nilai tengah 15,00. Proporsi responden terhadap nilai kualitas interaksi layanan menunjukkan $87,60 \%$ responden menyatakan kualitas interaksi layanan baik dan $12,40 \%$ responden menyatakan kualitas interaksi layanan kurang baik.

TABEL IX.

DISTRIBUSI JAWABAN KUALITAS ANTARMUKA

\begin{tabular}{|c|c|c|c|c|}
\hline \multirow[t]{2}{*}{ No } & \multirow[t]{2}{*}{ Dimensi Kualitas } & \multicolumn{3}{|c|}{ Jumlah Jawaban dan Persentase } \\
\hline & & $\begin{array}{c}\text { Tidak } \\
\text { Setuju n } \\
(\%)\end{array}$ & $\begin{array}{l}\text { Setuju } \\
\text { n (\%) }\end{array}$ & $\begin{array}{c}\text { Sangat } \\
\text { Setuju } \\
(\%)\end{array}$ \\
\hline \multicolumn{5}{|c|}{ User Interface Quality } \\
\hline 1 & $\begin{array}{l}\text { Menggunakan } \\
\text { Gambar yang tepat }\end{array}$ & $2(1,7)$ & $96(79,3)$ & $23(19.0)$ \\
\hline 2 & $\begin{array}{l}\text { Menggunakan font } \\
\text { sesuai }\end{array}$ & $4(3,3)$ & $90(74,4)$ & $27(22,3)$ \\
\hline 3 & $\begin{array}{l}\text { Desain halaman } \\
\text { sesuai }\end{array}$ & $2(1,7)$ & $94(77,7)$ & $25(20,7)$ \\
\hline 4 & $\begin{array}{l}\text { Link bekerja dengan } \\
\text { baik }\end{array}$ & $11(9,1)$ & $89(73,6)$ & $21(17,4)$ \\
\hline 5 & $\begin{array}{l}\text { Tata letak } \\
\text { terstruktur dan } \\
\text { konsisten }\end{array}$ & $7(5,8)$ & $91(75,2)$ & $23(19,0)$ \\
\hline 6 & $\begin{array}{l}\text { Mencerminkan } \\
\text { identitas universitas }\end{array}$ & $2(1,7)$ & $80(66,1)$ & $39(32,2)$ \\
\hline
\end{tabular}

TABEL $X$.

I Ketut Citra Adi Putra: Evaluasi Kualitas dan Kepuasan ...

\begin{tabular}{|c|c|c|c|c|}
\hline Variabel & $\begin{array}{c}n \\
(\%)\end{array}$ & Mean & $\begin{array}{c}\text { Std. } \\
\text { Deviation } \\
\end{array}$ & Median \\
\hline $\begin{array}{l}\text { Kualitas } \\
\text { Antarmuka }\end{array}$ & & 19,07 & 2,292 & 18,00 \\
\hline $\begin{array}{l}\text { Baik } \\
\text { Kurang Baik }\end{array}$ & \multicolumn{4}{|c|}{$106(87,60 \%)$} \\
\hline
\end{tabular}

Pada variabel kualitas antarmuka memiliki nilai rata-rata sebesar 19,07, standar deviasi 2,292 dan nilai tengah sebesar 18,00. Proporsi responden terhadap nilai kualitas antarmuka menunjukkan 106 atau $87,60 \%$ responden menyatakan kualitas kegunaan baik dan $12,40 \%$ responden menyatakan kualitas antarmuka kurang baik.

TABEL XI. DISTRIBUSI JAWABAN KEPUASAN PENGGUNA

\begin{tabular}{|c|c|c|c|c|}
\hline \multirow[t]{2}{*}{ No } & \multirow[t]{2}{*}{ Dimensi Kualitas } & \multicolumn{3}{|c|}{$\begin{array}{c}\text { Jumlah Jawaban dan } \\
\text { Persentase }\end{array}$} \\
\hline & & $\begin{array}{l}\text { Tidak } \\
\text { Setuju } \\
\text { n }(\%)\end{array}$ & $\begin{array}{l}\text { Setuju } \\
\text { n }(\%)\end{array}$ & $\begin{array}{c}\text { Sangat } \\
\text { Setuju } \\
(\%)\end{array}$ \\
\hline \multicolumn{5}{|c|}{ User Satisfaction } \\
\hline 1 & $\begin{array}{l}\text { Memberikan } \\
\text { informasi sesuai } \\
\text { kebutuhan }\end{array}$ & $4(3,3)$ & $84(69,4)$ & $33(27,3)$ \\
\hline 2 & $\begin{array}{l}\text { Informasi memenuhi } \\
\text { kebutuhan }\end{array}$ & $5(4,1)$ & $86(71,1)$ & $30(24,8)$ \\
\hline 3 & $\begin{array}{l}\text { Memberikan } \\
\text { informasi yang cukup }\end{array}$ & $2(1,7)$ & $90(74,4)$ & $29(24,0)$ \\
\hline 4 & $\begin{array}{l}\text { Informasi yang } \\
\text { diberikan akurat }\end{array}$ & $3(2,5)$ & $88(72,7)$ & $30(24,8)$ \\
\hline 5 & $\begin{array}{l}\text { Puas dengan } \\
\text { keakuratan informasi }\end{array}$ & $3(2,5)$ & $87(71,9)$ & $31(25,6)$ \\
\hline 6 & $\begin{array}{l}\text { Output disajikan } \\
\text { dengan format yang } \\
\text { sesuai }\end{array}$ & $1(0,8)$ & $92(76,0)$ & $28(23,1)$ \\
\hline 7 & $\begin{array}{l}\text { Menyediakan } \\
\text { Informasi yang jelas }\end{array}$ & $4(3,3)$ & $87(71,9)$ & $30(24,8)$ \\
\hline 8 & Mudah dimengerti & $4(3,3)$ & $79(65,3)$ & $38(31,4)$ \\
\hline 9 & Mudah digunakan & $4(3,3)$ & $79(65,3)$ & $38(31,4)$ \\
\hline 10 & Informasi tepat waktu & $10(8,3)$ & $82(67,8)$ & $29(24,0)$ \\
\hline 11 & $\begin{array}{l}\text { Memberikan } \\
\text { informasi terbaru }\end{array}$ & $9(7,4)$ & $85(70,2)$ & $27(22,3)$ \\
\hline 12 & Puas dengan layanan & $2(1,7)$ & $91(75,2)$ & $28(23,1)$ \\
\hline 13 & $\begin{array}{l}\text { Layanan sangat } \\
\text { bermanfaat }\end{array}$ & $0(0)$ & $84(69,4)$ & $37(30,6)$ \\
\hline
\end{tabular}

TABEL XII ANALISIS DESKRIFTIF KEPUASAN PENGGUNA

\begin{tabular}{|c|c|c|c|c|}
\hline Variabel & $\begin{array}{c}n \\
(\%)\end{array}$ & Mean & $\begin{array}{c}\text { Std. } \\
\text { Deviation }\end{array}$ & Median \\
\hline Kepuasan Pengguna & & 41,95 & 5,371 & 39,00 \\
\hline Puas & 106( & $60 \%)$ & & \\
\hline Kurang Puas & $15(1$ & $0 \%)$ & & \\
\hline
\end{tabular}

Pada tabel 9 menunjukan nilai rata-rata jawaban kuesioner kepuasan adalah sebesar 41,95, standar deviasi sebesar 5,371 dan nilai tengah sebesar 39,00. Proporsi responden terhadap nilai kepuasan pengguna sebanyak $87,60 \%$ responden p-ISSN:1693 - 2951; e-ISSN: 2503-2372 
menyatakan puas terhadap website IMISSU dan 12,40\% responden menyatakan kurang puas.

\section{B. Uji Validitas}

Penelitian yang dilakukan dengan jumlah 119 sampel, diperoleh hasil nilai $r$ tabel yakni sebesar 0,179, dari 39 pertanyaan yang diuji validitasnya, nilai validitas pada setiap pertanyaan bernilai diatas 0,179. Sehinga dapat ditarik kesimpulan setiap item pertanyaan yang ada bisa dijadikan sebagai alat ukur.

\section{Uji Reliabilitas}

Hasil uji terhadap instrumen menggunakan uji Cronbach's Alpha dapat dilihat pada tabel 10.

TABEL XIII.

HASIL UJI RELIABILITAS

\begin{tabular}{ccc}
\hline Variabel & Cronbach's Alpha & N of items \\
\hline X1 & 0,903 & 8 \\
X2 & 0,912 & 7 \\
X3 & 0,885 & 5 \\
X4 & 0,897 & 6 \\
Y & 0.966 & 13 \\
\hline
\end{tabular}

Dari hasil uji tersebut menunjukan nilai alpha lebih besar dari 0,70. Maka dapat disimpulkan semua variabel yang digunakan konsisten dan dapat digunakan sebagai alat ukur penelitian.

\section{Uji Normalitas}

Uji normalitas pada penelitian ini dilakukan dengan uji kolmogrov-smirnov. Dasar pengambilan keputusan yakni: bila nilai hasil sig. yang diperoleh lebih besar dari 0,05 maka data berdistribusi normal namun bila tidak dapat memenuhi syarat data tidak berdistribusi normal.

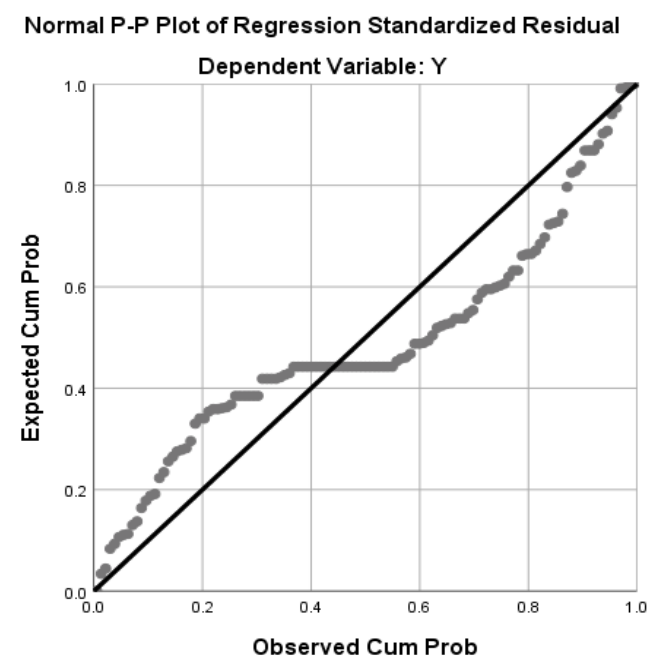

Gambar 3: Normal P-P Plot

Berdasarkan gambar 3. diketahui bahwa sebaran data pada penelitian tidak berdistribusi normal. Hal ini terlihat dari persebaran dari titik titik ploting yang menjauhi garis diagonal.

\section{E. Uji Rank Spearman}

Untuk menguji hubungan antar variabel terhadap kepuasan pengguna, diuji menggunakan uji rank spearman. Berdasarkan hasil uji yang dilakukan yang dapat dilihat pada tabel 11. nilai dari signifikansi (2-tailed) diperoleh adalah sebesar 0,000, nilai signifikansi tersebut lebih kecil dari 0,05 sehingga jika ditarik kesimpulan maka antara kualitas dengan kepuasan mempunyai hubungan yang signifikan.

TABEL XIV.

HASIL UJI SPEARMAN

\section{Correlations}

\begin{tabular}{ll|r|r|r} 
& & \multicolumn{1}{c|}{$\mathrm{X}$} & \multicolumn{1}{c}{$\mathrm{Y}$} \\
\hline $\begin{array}{l}\text { Spearman's } \\
\text { rho }\end{array}$ & $\mathrm{X}$ & Correlation Coefficient & 1.000 & $.855^{* *}$ \\
\cline { 3 - 5 } & & Sig. (2-tailed) &. & .000 \\
\cline { 2 - 5 } & $\mathrm{N}$ & 121 & 121 \\
\cline { 2 - 5 } & $\mathrm{Y}$ & Correlation Coefficient & $.855^{* *}$ & 1.000 \\
\cline { 3 - 5 } & & Sig. (2-tailed) & .000 &. \\
\cline { 2 - 5 } & $\mathrm{N}$ & 121 & 121 \\
\hline
\end{tabular}

**. Correlation is significant at the 0.01 level (2-tailed)

Bila dilihat dari nilai koefisien korelasi yakni sebesar $0,855^{* *}$, nilai ini menandakan tingkat kekuatan hubungan (korelasi) antara variabel kualitas dengan kepuasan pengguna adalah sebesar 0,855 atau dapat diartikan mempunyai hubungan yang sangat kuat.

\section{F. Analisis Linier Berganda}

TABEL XV.

HASIL UJI LINER BERGANDA

\section{Coefficients $^{\mathrm{a}}$}

Unstandardized Standardized

Coefficients Coefficients

\begin{tabular}{|c|c|c|c|c|c|c|}
\hline & & Coe & ients & Coefficients & & \\
\hline & Model & B & $\begin{array}{l}\text { Std. } \\
\text { Error }\end{array}$ & Beta & $\mathrm{t}$ & Sig. \\
\hline 1 & (Constant) & -.092 & 2.119 & & -.043 & .965 \\
\hline & $\mathrm{X} 1$ & .382 & .181 & .217 & 2.110 & .037 \\
\hline & $\mathrm{X} 2$ & .452 & .178 & .233 & 2.540 & .012 \\
\hline & $\mathrm{X} 3$ & .560 & .218 & .212 & 2.571 & .011 \\
\hline & $\mathrm{X} 4$ & .690 & .189 & .294 & 3.653 & .000 \\
\hline
\end{tabular}

a. Dependent Variable: Y

Berdasarkan dari tabel hasil uji liner berganda dapat diperoleh rumus regresi sebagai berikut:

$Y=(-0,092)+0,382 X_{1}+0,452 X_{2}+0,560 X_{3}+0,690 X_{4}+e$ Interpretasi dari regresi adalah sebagai berikut:

1) Konstanta (a)

Bila pada variabel bebas bernilai 0 , maka variabel terikat akan memiliki nilai sebesar -0,092;

2) Kualitas Kegunaan $\left(\mathrm{X}_{1}\right)$ terhadap Kepuasan (Y) Nilai dari koefisien kualitas informasi $\left(\mathrm{X}_{1}\right)$ adalah sebesar 0.382 . Nilai tersebut menandakan jika kualitas kegunaan meningkat sebanyak satu satuan dan variabel lain mempunyai nilai konstan, maka kepuasan pengguna akan meningkat sebanyak 0.382 satuan.

3) Kualitas Informasi $\left(\mathrm{X}_{2}\right)$ terhadap Kepuasan (Y) Nilai koefisien kualitas informasi $\left(\mathrm{X}_{2}\right)$ adalah sebesar 0.452. Hal ini menandakan jika kualitas informasi meningkat sebanyak satu satuan dan variabel lainnya 
konstan, maka kepuasan pengguna akan meningkat sebesar 0.452 satuan.

4) Kualitas Interaksi Layanan $\left(\mathrm{X}_{3}\right)$ terhadap Kepuasan $(\mathrm{Y})$ Nilai koefisien kualitas interaksi layanan $\left(\mathrm{X}_{3}\right)$ adalah sebesar 0.560. Hal ini menandakan jika kualitas interaksi layanan meningkat sebesar satu satuan dan variabel lain konstan, maka kepuasan pengguna akan meningkat sebesar 0.560 satuan.

5) Kualitas Antarmuka $\left(\mathrm{X}_{4}\right)$ terhadap Kepuasan (Y)

Nilai koefisien kualitas antarmuka $\left(\mathrm{X}_{4}\right)$ adalah sebesar 0.690. Hal ini menandakan jika kualitas antarmuka meningkat sebesar satu satuan dan variabel lain konstan, maka kepuasan pengguna akan meningkat sebesar 0.690 satuan.

\section{G. Uji Hipotesis}

Hubungan antara variabel independen terhadap variabel dependen dapat diuji secara parsial (uji t). Berdasarkan tabel 12 maka diperoleh hipotesis sebagai berikut:

1) Hipotesis Pertama $\left(\mathrm{H}_{1}\right)$

Diketahui nilai signifikansi variabel $\mathrm{X}_{1}$ sebesar 0.037 yang berarti bahwa kualitas dari kegunaan berpengaruh secara signifikan terhadap kepuasan pengguna. Jika melihat dari nilai koefisien $\beta$ dari $X_{1} \quad(0,382)$ menunjukan kualitas dari kegunaan memiliki arah positif terhadap kepuasan pengguna. Sehingga hipotesis pertama $\left(\mathrm{H}_{1}\right)$ dapat diterima. Dimana bila kualitas kegunaan semakin tinggi maka tingkat kepuasan pengguna juga akan semakin tinggi.

2) Hipotesis Kedua $\left(\mathrm{H}_{2}\right)$

Diketahui nilai signifikansi variabel $\mathrm{X}_{2}$ sebesar 0.012 berarti bahwa kualitas dari informasi berpengaruh secara signifikan terhadap kepuasan pengguna. Jika dilihat dari nilai koefisien $\beta$ dari $\mathrm{X}_{2} \quad(0,452)$ menunjukan kualitas dari informasi memiliki pengaruh ke arah positif terhadap kepuasan pengguna. Hipotesis kedua $\left(\mathrm{H}_{2}\right)$ dapat diterima. Dimana bila kualitas informasi semakin tinggi maka kepuasan pengguna juga semakin tinggi.

3) Hipotesis Ketiga $\left(\mathrm{H}_{3}\right)$

Diketahui nilai signifikansi variabel $\mathrm{X}_{3}$ sebesar 0.011 berarti kualitas interaksi layanan secara signifikan berpengaruh terhadap kepuasan pengguna. Jika melihat dari nilai koefisien $\beta$ dari $\mathrm{X}_{3}(0,560)$ menunjukan bahawa kualitas layanan berpengaruh pada kepuasan pengguna dengan arah yang positif. Hipotesis ketiga $\left(\mathrm{H}_{3}\right)$ dapat diterima. Dimana bila kualitas interaksi layanan semakin tinggi maka semakin tinggi pula tingkat kepuasan pengguna.

4) Hipotesis Keempat $\left(\mathrm{H}_{4}\right)$

Diketahui nilai signifikansi variabel $\mathrm{X}_{4}$ sebesar 0.001 berarti kualitas antarmuka secara signifikan berpengaruh terhadap kepuasan pengguna. Jika melihat dari nilai koefisien $\beta$ dari $\mathrm{X}_{4}(0,690)$ menunjukan bahawa kualitas layanan berpengaruh pada kepuasan pengguna dengan arah yang positif. Hipotesis keempat $\left(\mathrm{H}_{4}\right)$ dapat diterima. Dimana bila kualitas antarmuka I Ketut Citra Adi Putra: Evaluasi Kualitas dan Kepuasan ... semakin tinggi maka semakin tinggi pula tingkat kepuasan pengguna.

Dari hasil uji $\mathrm{t}$ dapat diketahui juga bahwa kualitas antarmuka lebih berpengaruh pada kepuasan pengguna. Hal ini dapat dilihat dari nilai Standardized Coefficients (beta) kualitas antarmuka sebesar 0,294 dibandingkan dengan kualitas kegunaan, kualitas informasi dan kualitas layanan.

\section{H. Pembahasan Hasil Penelitian}

Pengaruh dari variabel bebas dan variabel terikat telah dijabarkan sebelumnya. Berdasarkan pengujian yang telah dilaksanakan, pembahasan dari hasil penelitian adalah sebagai berikut ini.

1) Kualitas kegunaan dari web IMISSU memiliki tingkat kualitas yang baik. Pengaruh kualitas kegunaan terhadap kepuasan pengguna berpengaruh secara signifikan dan memiliki pengaruh kearah positif. Hasil Penelitian ini tidak sesuai dengan [1][6][18] yang menyatakan tidak ada hubungan antara Usability dan User Satisfaction. Pada penelitian yang dilakukan [1] kepuasan pengguna tidak berpengaruh terhadap kualitas kegunaan disebabkan karena website memiliki tampilan yang kurang menarik dan tidak mengandung kompetensi. Penelitian tersebut menunjukkan hasil yang serupa dengan penelitian lainnya yakni oleh [19]. Penelitian tersebut membahas tentang hubungan antara kualitas website politeknik negeri sriwijaya dengan kepuasan mahasiswa sebagai pengguna. Penelitian oleh [20] juga mendapatkan hal yang sama, yaitu ada hubungan yang terjadi pada kualitas kegunaan dan kepuasan pengguna. Hasil penelitian ini membuktikan bahwa jika kualitas kegunaan baik maka tingkat kepuasan pengguna layanan website menjadi semakin tinggi.

2) Kualitas informasi dari web IMISSU memiliki tingkat kualitas yang baik. Kualitas informasi terhadap kepuasan pengguna berpengaruh secara signifikan dan memiliki pengaruh kearah positif. Hasil penelitian ini bertolak belakang dengan penelitian yang dilakukan oleh [1][18][20], dalam penelitiannya dikatakan kualitas informasi berpengaruh tidak signifikan. Akan tetapi hasil dari penelitian ini memperlihatkan hasil yang sama dengan penelitian lain yaitu [6][19] kualitas dari informasi dikatakan berpengaruh positif terhadap kepuasan pengguna. Kualitas dari informasi harus berisikan informasi yang akurat, dapat dipercaya, tepat waktu, relevan, mudah dipahami, detail, dan disajikan sesuai format. Jika keseluruhan kriteria informasi tersebut ada maka dapat dikatakan bahwa kualitas baik menyebakan semakin meningkatnya tingkat kepuasan pengguna.

3) Kualitas Layanan dari web IMISSU memiliki tingkat kualitas yang baik. Pengaruh kualitas layanan terhadap kepuasan pengguna secara signifikan berpengaruh kearah positif. Hasil dari penelitian tidak sesuai dengan penelitian yang telah dilaksakan oleh [21][19] p-ISSN:1693 - 2951; e-ISSN: 2503-2372 
menyebutkan dalam penelitiannya bahwa kualitas dari layanan berpengaruh ke arah negatif terhadap kepuasan pengguna. Terlihat dari hasil uji yang dilakukan, hasil dari uji t mendapatkan nilai yang lebih kecil dari nilai $t$ tabel, nilai signifikan yang diperoleh juga lebih besar dari 0,05 .

Sebaliknya penelitian yang dilakukan oleh [1][18][20] menyebutkan hasil yang sama yakni kualitas dari layanan secara signifikan memiliki pengaruh kearah positif terhadap kepuasan pengguna.

Kualitas antarmuka dari website IMISSU memiliki tingkat kualitas yang baik. Pengaruh kualitas antarmuka terhadap kepuasan pengguna berpengaruh secara signifikan dan memiliki pengaruh kearah positif. Penelitian yang telah dilakukan oleh [19]. Menunjukan hasil yang sama bahwa kualitas antarmuka secara signifikan berpengaruh terhadap kepuasan pengguna kearah yang positif. Hal tersebut dibuktikan dari hasil hitung t yang bernilai lebih tinggi dari nilai t tabel. Signifikan nilai yang diperoleh lebih rendah dari tingkat kesalahan 0,05.

\section{Kesimpulan}

Penelitian ini memaparkan evaluasi kualitas dan kepuasan pengguna terhadap website IMISSU. Berdasarkan Hasil evaluasi kualitas website terhadap kepuasan pengguna dapat disimpulkan sebagai berikut:

1. Hasil analisis korelasi rank spearman diperoleh bahwa variabel kualitas dan kepuasan pengguna memiliki hubungan yang sangat kuat. Terbukti dari besar nilai korelasi yang diperoleh yakni sebesar 0,855 .

2. Dari hasil uji hipotesis diperoleh nilai signifikansi lebih besar dari nilai probabilitas. Nilai pada variabel kualitas kegunaan 0,037, kualitas informasi 0,012, kualitas layanan 0,011 dan kualitas antarmuka 0,001 lebih besar dari nilai probabilitas 0,05 . Secara keseluruhan hipotesis yang diajukan dapat diterima, yang berarti ada pengaruh kualitas kegunaan (X1), kualitas informasi (X2), kualitas layanan (X3) dan kualitas antarmuka (X4) terhadap kepuasan pengguna (Y).

3. Hasil dari penelitian ini menunjukan bahwa antara kualitas kegunaan berpengaruh terhadap kepuasan pengguna dengan nilai signifikansi sebesar 0.037 , nilai koefisien $\beta$ sebesar 0,382 menunjukan arah yang positif terhadap kepuasan pengguna. Sedangkan untuk kualitas informasi terhadap kepuasan berpengaruh dengan nilai signifikansi sebesar 0.012, nilai koefisien $\beta$ sebesar 0,452 menunjukan arah yang positif terhadap kepuasan pengguna. kualitas layanan terhadap kepuasan berpengaruh dengan nilai signifikansi sebesar 0.011 , nilai koefisien $\beta$ sebesar 0,560 menunjukan arah yang positif terhadap kepuasan pengguna, dan kualitas antarmuka terhadap kepuasan berpengaruh dengan nilai signifikansi sebesar 0.001 , nilai koefisien $\beta$ sebesar 0,690 menunjukan arah yang positif terhadap kepuasan pengguna.

\section{REFERENSI}

[1] M. M. Webqual, N. Q. Nada, and S. Wibowo, "Pengukuran Kualitas
Layanan Sistem Informasi Akademik," J. Inform. Upgris, pp. 122-131, 2015.

[2] G. P. Utama, A. Hamzah, and U. Lestari, "Jurnal SCRIPT Vol . 4 No . 2 Juni 2017 ISSN : 2338-6304," J. Scr., vol. 4, no. 2, pp. 132-138, 2017.

[3] E. E. Barus, Suprapto, and A. D. Herlambang, "Analisis Kualitas Website Tribunnews.com Menggunakan Metode Webqual dan Importance Performance Analysis," J. Pengemb. Teknol. Inf. dan Ilmu Komput., vol. 2, no. 4, pp. 1483-1491, 2018.

[4] H. Aryadita, D. A. Widyastuti, and N. H. Wardani, "ANALISIS KUALITAS LAYANAN WEBSITE E-COMMERCE TERHADAP KEPUASAN PENGGUNA MENGGUNAKAN METODE,"Stud. Inform. J. Sist. Inf., vol. 10, no. 1, pp. 29-35, 2017.

[5] S. R. Arifin, E. Nugroho, and B. S. Hantono, "Analisis Kualitas Layanan Website Universitas Hasanuddin Dengan Metode Webqual 4.0 Modifikasi," Teknomatika, vol. 8, no. 1, pp. 81-92, 2015.

[6] A. Masthori, H. A. Nugroho, and R. Ferdiana, "Penggunaan Metode Webqual Modifikasi dalam Evaluasi Kualitas Layanan Website Pemerintah Daerah The Use of Modified Webqual Method in Evaluation of Website Service Quality of Local Government," J. Pekommas, vol. 1, no. 1, pp. 57-68, 2016.

[7] I. M. O. Laksmidewi, N.L.A, Linawati, Widyantara, "Evaluasi Sistem Informasi Manajemen Kepegawaian dengan DS5 dan DS9 COBIT 4 . 1 Studi Kasus: Pemprov Bali," Maj. Ilm. Teknol. Elektro, vol. 17, no. 1, pp. 25-32, 2018.

[8] S. Ellyusman, "Analisis Kualitas Sistem Informasi Akademik Menggunakan Metode Importance Performance Analysis (Ipa) (Studi Kasus Pada Website Portal Akademik Universitas Xyz Bandung)," $J$. Kaji. Inf. dan Perpust., vol. 5, no. 1, p. 51, 2018.

[9] P. A. Kurniawijaya, D. M. Wiharta, and N. P. Sastra, "Perencanaan Strategis Menuju Webometrics Dan 4ICU," Maj. Ilm. Teknol. Elektro, vol. 18, no. 1, pp. 95-100, 2019.

[10] N. Purnama, I. K. G. D. Putra, and P. A. Bayupati, "No Title," Maj. Ilm. Teknol. Elektro, vol. 13, no. 2, pp. 8-15, 2014.

[11] Syaifullah and D. O. Soemantri, "PENGUKURAN KUALITAS WEBSITE MENGGUNAKAN METODE WEBQUAL $4.0, " J$. Rekayasa dan Manaj. Sist. Inf., vol. 2, no. 1, pp. 19-25, 2016.

[12] S. Kabadayi and R. Gupta, "Managing motives and design to influence web site revisits," J. Res. Interact. Mark., vol. 5, no. 2, 2011.

[13] A. Supriyatna and J. M. Informatika, "PERPUSTAKAAN DENGAN MENGGUNAKAN PIECES FRAMEWORK," vol. XI, no. 1, pp. 43$52,2015$.

[14] Elmayati and C. Wulandari, "Evaluasi Kualitas Website SMA Negeri 4 Lubuklinggau Menggunakan Metode WebQual," J. Sist. Inf. Musirawas, vol. 3, no. 2, pp. 102-111, 2018.

[15] Hekhmatyar dan Supriadi, "Measurement Satisfaction Information System Quality Service On BSI Using Webqual And CSI," Indones. J. onComputer Inf. Technol., vol. ISSN: 2527, no. 2, pp. 1-6, 2017.

[16] A. C. Sembiring, "Meningkatkan Kepuasan Pelanggan dengan Mempertimbangkan Kualitas Meningkatkan Kepuasan Pelanggan dengan Mempertimbangkan Kualitas Layanan dan Harga," Anita Christine Sembiring Progr., vol. 2, no. 1, pp. 22-28, 2018.

[17] R. A. Kurniawati, A. Kusyanti, and Y. T. Mursityo, "Analisis Pengaruh Kualitas Website Terhadap Kepuasan Pelanggan Mister Aladin Dengan Menggunakan Webqual 4 . 0," vol. 2, no. 3, pp. 1151-1160, 2018.

[18] S. Monalisa, "Analisis Kualitas Layanan Website Terhadap Kepuasan Mahasiswa dengan Penerapan Metode Webqual ( Studi Kasus: UIN Suska Riau )," J. Sains, Teknol. dan Ind. ISSN 2407-0939, vol. 13, no. 2, pp. 181-189, 2016.

[19] A. Manik, I. Salamah, and E. Susanti, "Fakultas Teknik - Universitas Muria Kudus 355," in Posiding SNATIF, 2017, pp. 355-361.

[20] D. Napitupulu, "Analysis of Factors Affecting The Website Quality (Study Case: XYZ University)," Int. J. Adv. Sci. Eng. Inf. Technol., vol. 7, no. 3, p. 792, 2017.

[21] Warjiyono and C. M. Hellyana, "Pengukuran Kualitas Website Pemerintah Desa Jagalempeni Quality Measurement of Jagalempeni Village Government Website Using Webqual 4.0 Methode," J. Teknol. Inf. dan Ilmu Komput., vol. 5, no. 2, pp. 139-146, 2018. 